\title{
HUBUNGAN STATUS GIZI DENGAN KASUS GIGI BERJEJAL PADA MURID SMP KECAMATAN MEDAN BARU
}

\section{(RELATIONSHIP BETWEEN NUTRITIONAL STATUS AND DENTAL CROWDING OF JUNIOR HIGH SCHOOL STUDENTS IN MEDAN BARU)}

\author{
Erliera, Rika Mayasari Alamsyah, Novita Zein Harahap \\ Departemen Ortodonsia, \\ Departemen Ilmu kedokkteran Gigi Pencegahan/ Kesehatan Gigi Masyarakat \\ Fakultas Kedokteran Gigi, Universitas Sumatera Utara \\ J1. Alumni no.2 Kampus USU Medan \\ E-mail: er_liera@yahoo.com
}

\begin{abstract}
Dental crowding is the most common orthodontic cases that occurs in $2 / 3$ of the human population. Dental crowding influenced by many factors, one of them is nutrition factor that can be measured by nutritional status. This study aimed to know relation of nutritional status with dental crowding case in junior high school students in Medan Baru. The design of research was cross sectional. Sample was determined by using multistage random sampling method.The total of samples was 180 subjects from 4 schools in Medan Baru (SMP Negeri 10 Medan, SMP Swasta Al Bukhari Muslim, SMP Swasta Nasrani 1, and SMP Swasta Nurul Hasanah) aged 12-15 years. Nutritional status was classified by BMI for age CDC 2000 index and the dental crowding case was determined by Proffit. Relation between nutritional status and dental crowding case were analysed by using chi-square test. The result of study showed that the most nutritional status was the normal category $72,78 \%$ and there was no significant value about dental crowding cases (crowding $49,44 \%$ and no crowding 50,56\%). There was no relation about nutritional status and dental crowding case in junior high school students at Medan Baru ( $\mathrm{p}=0,750)$. In conclusion, there was no relation about nutritional status and dental crowding case of junior high school students in Medan Baru.
\end{abstract}

Key words: nutritional status, dental crowding, junior high school student

\begin{abstract}
Abstrak
Gigi berjejal (dental crowding) merupakan kasus ortodonti yang paling sering terjadi bahkan hampir 2/3 dari populasi manusia mengalami kondisi ini. Terjadinya kasus gigi berjejal dipengaruhi oleh banyak faktor, salah satunya adalah faktor gizi, yang dapat diukur melalui skala status gizi. Penelitian ini bertujuan untuk mengetahui hubungan antara status gizi dengan kasus gigi berjejal pada siswa SMP di Kecamatan Medan Baru. Jenis penelitian ini adalah cross sectional. Penentuan sampel dilakukan dengan menggunakan teknik multistagerandom sampling. Sampel penelitian ini berjumlah 180 orang dan berasal dari 4 sekolah yang berada di Kecamatan Medan Baru (SMP Negeri 10 Medan, SMP Swasta Al Bukhari Muslim, SMP Swasta Nasrani 1, dan SMP Swasta Nurul Hasanah) yang berusia 12-15 tahun. Status gizi diklasifikasikan berdasarkan indeks BMI for age CDC 2000 dan penentuan gigi berjejal diklasifikasikan berdasarkan derajat keparahan yang dikemukakan Proffit. Hubungan status gizi dengan kasus gigi berjejal dianalisis menggunakan chi square test. Hasil penelitian menunjukkan sebagian besar sampel memiliki status gizi dengan kategori normal yakni sejumlah 131 orang $(72,78 \%)$ dan terdapat prevalensi yang tidak signifikan antara responden yang memiliki gigi berjejal dan tidak berjejal ,yakni gigi berjejal berjumlah 89 orang $(49,44 \%)$ dan gigi tidak berjejal sebanyak 91 orang $(50,56 \%)$. Tidak terdapat hubungan antara status gizi dengan kasus gigi berjejal pada siswa SMP Kecamatan Medan Baru dengan nilai $\mathrm{p}=0,750$. Sebagai kesimpulan, tidak terdapat hubungan antara status gizi dengan kasus gigi berjejal pada sampel siswa SMP di Kecamatan Medan Baru.
\end{abstract}

Kata kunci: status gizi, gigi berjejal, siswa SMP 


\section{PENDAHULUAN}

Maloklusi merupakan keadaan yang menyimpang dari oklusi normal, meliputi ketidakteraturan gigigeligi dalam lengkung rahang. ${ }^{1} \mathrm{Di}$ Indonesia, prevalensi maloklusi mencapai $80 \%$ dan menduduki urutan ketiga setelah karies dan penyakit periodontal. Hal ini cukup memprihatinkan, walaupun maloklusi bukan merupakan penyakit yang disebabkan oleh mikroorganisme, bakteri, maupun virus tetapi kelainan ini dapat mengganggu keadaan rongga mulut. ${ }^{2}$ Maloklusi dapat menyebabkan gangguan pada fungsi pengunyahan, fungsi bicara, mengganggu estetis wajah, bahkan dapat memicu terjadinya penyakit. Salah satu kondisi maloklusi yang dapat memicu terjadinya penyakit gigi dan periodontal. ${ }^{3}$

Gigi berjejal (dental crowding) merupakan kasus ortodonti yang paling sering terjadi bahkan hampir $2 / 3$ dari populasi manusia mengalami kondisi ini. ${ }^{4}$ Gigi berjejal didefinisikan sebagai suatu keadaan ketidakseimbangan antara ruangan yang dibutuhkan gigi-geligi dengan ruangan yang tersedia pada lengkung rahang sehingga gigi-geligi akan saling bertimpa dan mengalami rotasi. ${ }^{5}$ Diagnosa crowding pada gigi permanen dapat ditentukan pada usia sekitar 12-14 tahun karena pada usia tersebut diperkirakan gigi permanen telah tumbuh lengkap sejumlah 28 gigi sampai pada gigi molar kedua di masing-masing kuadran. ${ }^{4}$

Terjadinya kasus gigi berjejal dipengaruhi oleh faktor herediter dan lingkungan. Faktor herediter yang menyebabkan gigi berjejal adalah pengaruh susunan genetik yang menentukan karakteristik rahang dan gigi seseorang. Sedangkan faktor lingkungan yang menyebabkan terjadinya gigi berjejal adalah beberapa kondisi yang terjadi pada gigi desidui (premature loss, karies, dan persistensi), kebiasaan mengonsumsi makanan lunak pada anak, adanya tekanan akibat erupsi gigi molar ketiga, dan adanya kebiasaan buruk oral (oral habits). ${ }^{4,6,7}$

Selain faktor tersebut, faktor gizi juga diduga dapat mempengaruhi terjadinya kasus gigi berjejal. Gizi adalah kumpulan zat biokimia yang dihasilkan oleh beberapa sumber, yang umumnya berasal dari makanan dan digunakan untuk proses menghasilkan energi, pertumbuhan, perkembangan, dan pemeliharaan tubuh. ${ }^{8}$ Kecukupan gizi individu untuk tumbuh dan berkembang dapat dicapai dengan mengonsumsi makanan yang beragam, bergizi seimbang, dan aman. Penilaian kecukupan gizi seorang anak biasanya diukur melalui skala status gizi. ${ }^{9}$

Status gizi secara umum berpengaruh dalam pertumbuhan dan perkembangan tubuh serta khususnya pada pertumbuhan dan perkembangan gigi dan mulut. ${ }^{4}$ Menurut beberapa penelitian, status gizi yang kurang baik akan berdampak pada pertumbuhan dan perkembangan gigi dan mulut seperti, terjadinya malformasi gigi, tingginya prevalensi karies, mudahnya terjadi cedera pada jaringan lunak, maloklusi pada gigi, terhambatnya perkembangan tulang wajah dan rahang, serta terdapatnya susunan gigi yang berjejal. ${ }^{10-12}$ Thomaz dkk. melakukan penelitian tentang hubungan malnutrisi dengan kasus gigi berjejal pada gigi desidui pada sampel 794 anak dengan landasan pengukuran status gizi secara antropometri yaitu membagikan antara berat badan dan usia anak (Weight/Age). Hasil penelitian tersebut menyatakan bahwa terdapat hubungan yang signifikan antara rendahnya status gizi anak secara antropometri dengan banyaknya kasus gigi berjejal pada gigi desidui. $^{11}$

Berdasarkan uraian di atas, maka status gizi diperkirakan akan berpengaruh pada pertumbuhan dan perkembangan gigi dan mulut seorang anak. Dapat dilihat pula bahwa status gizi memiliki hubungan dengan kasus gigi berjejal. Tujuan penelitian ini adalah untuk mengetahui hubungan antara status gizi dengan kasus gigi berjejal pada murid SMP di Kecamatan Medan Baru. Penelitian dilakukan pada murid SMP yang berusia 12-14 tahun karena telah memiliki gigi permanen lengkap (sampai dengan M2), sehingga memungkinkan dilakukan pemeriksaan secara homogen dan untuk mengetahui faktor predisposisi lain yang dapat menyebabkan gigi berjejal seperti kebiasaan buruk oral. Penelitian dilakukan di Kecamatan Medan Baru karena wilayah kecamatan ini terletak pada daerah pusat kota dan pinggiran kota sehingga diharapkan dapat mewakili keanekaragaman status gizi anak di berbagai tingkat ekonomi. Selain itu, kemungkinan besar sampel yang digunakan akan lebih majemuk karena Kecamatan Medan baru tergolong kecamatan yang padat penduduk dengan luas wilayah $5,41 \mathrm{~km}^{2}$ dan jumlah penduduk 39.516 jiwa. ${ }^{13}$

\section{BAHAN DAN METODE}

Jenis penelitian ini adalah cross sectional. Populasi pada penelitian ini adalah seluruh murid kelas VII, VIII, dan IX yang bersekolah di SMP pada Kecamatan Medan Baru. Penentuan sampel dilakukan dengan menggunakan teknik multistagerandom sampling. Sampel berjumlah 180 orang dan berasal dari 4 sekolah yang berada di Kecamatan Medan Baru (SMP Negeri 10 Medan, SMP Swasta Al Bukhari Muslim, SMP Swasta Nasrani 1, dan SMP Swasta Nurul Hasanah) yang berusia 12-15 tahun. Status gizi diklasifikasikan menggunakan indeks BMI forage CDC 2000 dan penentuan gigi berjejal diklasifikasikan berdasarkan derajat keparahan yang 
dikemukakan oleh Proffit. Analisis data untuk melihat hubungan antara status gizi dengan kasus gigi berjejal menggunakan uji chi square.

\section{HASIL}

Dari 180 orang responden yang diteliti, jumlah sampel laki-laki lebih sedikit dibandingkan perempuan, terdapat 82 orang responden laki-laki $(45,56$ $\%)$ dan 98 orang responden perempuan $(54,44 \%)$. Berdasarkan usia responden, sebagian besar responden berusia 14 tahun yaitu $40,00 \%$ dan paling sedikit usia 15 tahun yaitu 8,33\% (Tabel 1).

Tabel 1. Karakteristik responden berdasarkan jenis kelamin dan usia $(n=180)$

\begin{tabular}{lcc}
\hline Karakteristik & $\mathrm{n}$ & $\%$ \\
\hline Jenis Kelamin & & \\
Laki-laki & 82 & 45,56 \\
Perempuan & 98 & 54,44 \\
Usia (Tahun) & & \\
$\quad 12$ & 40 & 22,22 \\
13 & 53 & 29,44 \\
14 & 72 & 40,00 \\
15 & 15 & 8,33 \\
\hline
\end{tabular}

Hasil perhitungan Indeks Massa Tubuh (IMT) sampel diklasifikasikan dalam 4 kategori, yaitu gizi buruk, normal, gizi berlebih, dan obesitas. Dari total 180 sampel dalam penelitian ini, terdapat kategori gizi buruk 14 orang (7,78\%), kategori normal 131 orang $(72,78 \%)$, kategori gizi berlebih 24 orang $(13,33 \%)$, dan kategori obesitas 11 orang $(6,11 \%)$ (Tabel 2).

Tabel 2. Kategori status gizi (IMT) responden $(n=180)$

\begin{tabular}{lcc}
\hline \multicolumn{1}{r}{ Kategori IMT } & $\mathrm{n}$ & $\%$ \\
\hline Gizi buruk & 14 & 7,78 \\
Normal & 131 & 72,78 \\
Gizi berlebih & 24 & 13,33 \\
Obesitas & 11 & 6,11 \\
\hline
\end{tabular}

Hasil penelitian menunjukkan jumlah responden dengan gigi berjejal 89 orang $(49,44 \%)$ dan yang tidak memiliki gigi berjejal sebanyak 91 orang $(50,56 \%)$ (Tabel 3).

Tabel 3. Prevalensi kasus gigi berjejal pada responden $(n=180)$

\begin{tabular}{lcc}
\hline Kasus gigi berjejal & $\mathrm{n}$ & $\%$ \\
\hline Ada & 89 & 49,44 \\
Tidak ada & 91 & 50,56 \\
\hline
\end{tabular}

Pada Tabel 4 terlihat bahwa dari 131 responden yang memiliki status gizi normal, terdapat lebih ba- nyak responden dengan kasus gigi berjejal, yaitu 68 orang. Kasus gigi berjejal bahkan dialami oleh responden yang memiliki status gizi berlebih dan obesitas. Hal ini menunjukkan bahwa baik atau buruknya status gizi responden, tidak mempengaruhi ada atau tidaknya kasus gigi berjejal. Hasil analisis juga menunjukkan bahwa tidak adanya hubungan yang signifikan antara status gizi dengan kasus gigi berjejal $(p=0,750)$.

Tabel. 4. Hubungan status gizi (IMT) dengan kasus gigi berjejal $(n=180)$

\begin{tabular}{|c|c|c|c|c|c|}
\hline \multirow{3}{*}{$\begin{array}{c}\text { Status gizi } \\
\text { (IMT) }\end{array}$} & \multicolumn{4}{|c|}{ Gigi berjejal } & \multirow{3}{*}{$\begin{array}{c}\text { Hasil } \\
\text { analisis }\end{array}$} \\
\hline & \multicolumn{2}{|c|}{ Ada } & \multicolumn{2}{|c|}{ Tidak ada } & \\
\hline & $\mathrm{n}$ & $\%$ & $\mathrm{n}$ & $\%$ & \\
\hline Gizi buruk & 6 & 42,86 & 8 & 57,14 & \multirow{4}{*}{$\mathrm{p}=0,750$} \\
\hline Normal & 68 & 51,91 & 63 & 48,09 & \\
\hline Gizi berlebih & 10 & 41,67 & 14 & 58,33 & \\
\hline Obesitas & 5 & 45,45 & 6 & 54,55 & \\
\hline
\end{tabular}

\section{PEMBAHASAN}

Pada penelitian ini, diperoleh bahwa status gizi paling dominan berada pada kategori normal $(72,78$ $\%)$. Hasil penelitian ini sejalan dengan hasil penelitian yang dilakukan oleh Pramitya dan Valentina pada 280 orang remaja di perkotaan yaitu Kota Denpasar pada tahun 2012, dimana status gizi dominan responden berada pada kategori normal $(61,07 \%) .{ }^{14}$ Hal ini juga juga terlihat pada hasil penelitian Dwiningsih pada daerah perkotaan tahun 2011 dengan responden berjumlah 49 orang yang merupakan murid SMP Negeri 3 Semarang, yang mana responden memiliki status gizi normal $79,59 \%$. $^{15}$ Hasil penelitian ini kemungkinan besar disebabkan oleh lokasi penelitian yang berada di perkotaan sehingga pengetahuan dan kesadaran orangtua akan nutrisi anak sudah cukup besar serta ketersediaan pangan juga mudah dijangkau.

Dari hasil penelitian ini didapatkan prevalensi kasus gigi berjejal yang cukup tinggi yaitu sejumlah $49,44 \%$. Hal ini sesuai dengan penelitian Ahammed dkk. tentang prevalensi maloklusi pada anak yatim. usia 12-15 tahun dengan menggunakan indeks Dental Aesthetic dari 165 sampel. pada 2013, ditemukan bahwa prevalensi tertinggi maloklusi yang terjadi adalah kasus gigi berjejal yaitu sebanyak $38,8 \%{ }^{16}$ Hal tersebut juga sejalan dengan hasil penelitian dkk. tentang prevalensi maloklusi dan kebutuhan perawatan ortodonti pada anak usia 12- 15 tahun di India pada tahun 2013, menyatakan bahwa prevalensi gigi berjejal merupakan prevalensi maloklusi tertinggi yaitu sebanyak $40,2 \%$ pada sampel sebanyak 887 anak. ${ }^{17}$ Tingginya prevalensi gigi berjejal pada usia remaja sekitar 12-15 tahun kemungkinan disebabkan oleh pada usia tersebut responden masih 
dalam proses pertumbuhan dan perkembangan. Sekitar $98 \%$ dari pertumbuhan wajah akan berhenti pada usia 15 tahun untuk perempuan dan pada usia 1718 tahun pada laki-laki. ${ }^{18}$

Hasil uji statistik chi-square pada penelitian ini, menunjukkan bahwa tidak terdapat hubungan antara status gizi dengan kasus gigi berjejal pada murid SMP Kecamatan Medan Baru. Hasil penelitian ini sejalan dengan penelitian Thomaz dkk. pada tahun 2010 dengan sampel 2060 anak yang berusia 12-15 tahun di Salvador, Brazil diperoleh hasil bahwa tidak terdapat hubungan antara gizi buruk dengan kasus gigi berjejal. ${ }^{10}$ Hasil penelitian ini mungkin karena terjadinya gigi berjejal dapat dipengaruhi oleh banyak faktor, yakni faktor herediter dan faktor lingkungan. ${ }^{4,6,7}$ Salah satu faktor herediter yang mempengaruhi terjadinya kasus gigi berjejal adalah panjang lengkung rahang. Menurut penelitian Hamid tahun 2005 dengan responden sejumlah 80 orang usia 14-18 tahun diperoleh 40 orang kasus gigi berjejal dan 40 orang gigi tidak berjejal, karena panjang lengkung rahang mempengaruhi terjadinya gigi berjejal. Hal ini dapat dilihat dari hasil penelitian dimana responden yang mengalami gigi berjejal memiliki rata-rata panjang lengkung rahang yang lebih kecil dibandingkan responden dengan gigi yang tidak berjejal. ${ }^{5}$ Faktor lain yang mempengaruhi terjadinya kasus gigi berjejal adalah karakteristik gigi, misalnya ukuran dan jumlah gigi. Menurut penelitian yang dilakukan oleh Maryam dan Tahereh tahun 2007 dengan 60 orang responden, disebutkan bahwa terdapat pengaruh antara ukuran gigi dengan terjadinya kasus gigi berjejal. Hal ini dilihat dari hasil penelitian pada responden dengan kasus gigi berjejal terdapat ukuran gigi yang lebih besar dibandingkan pada responden dengan gigi yang tidak berjejal. ${ }^{19}$ Sedangkan menurut Bhalajhi pada tahun 2006, supernumerary teeth (jumlah gigi yang berlebih) dapat menyebabkan gigi berjejal, misalnya terdapatnya gigi supplemental insisif lateral dapat menyebabkan gigi anterior maksila berjejal oleh karena kurangnya tempat untuk tumbuhnya gigi. ${ }^{20}$ Keadaan lainnya yang mempengaruhi terjadinya kasus gigi berjejal adalah beberapa kondisi yang terjadi pada gigi desidui. Tingginya prevalensi gigi berjejal juga kemungkinan disebabkan oleh adanya karies gigi desidui dan ekstraksi gigi molar desidui, yang mana dapat memicu terjadinya migrasi gigi premolar pertama, inklinasi, dan rotasi. ${ }^{17}$ Adapun keadaan lain yang mempengaruhi terjadinya gigi berjejal adalah akibat erupsi gigi molar tiga. Menurut Proffit, erupsi gigi molar tiga juga mempengaruhi terjadinya gigi berjejal. Hal ini disebabkan karena mayoritas orang mengalami impaksi gigi molar ketiga diakibatkan oleh ketersediaan rahang yang terbatas dan lambat laun dapat mengakibatkan late incisor crowding. ${ }^{6}$ Sebagai kesimpulan, tidak terdapat hubungan antara status gizi dengan kasus gigi berjejal pada sampel murid SMP di Kecamatan Medan Baru $(p=0,750)$.

\section{Daftar Pustaka}

1. Djunaid A, Gunawan PN, Khoman JA. Gambaran pengetahuan tentang tampilan maloklusi pada Siswa Sekolah Menengah Pertama Kristen 67 Imanuel Bahu. Jurnal e-Gigi. 2013; 1(1): 28-9.

2. Wagiran DIL, Kaunang WPJ, Wowor VNS. Kualitas hidup remaja SMA Negeri 6 Manado yang mengalami maloklusi. Jurnal Kedokteran Komunitas dan Tropik. 2014; 2(2): 86.

3. Foster TD. Buku ajar ortodonti. Alih bahasa. Yuwono L. Jakarta: EGC, 2012: 30.

4. Heasman P. Restorative dentistry, pediatric dentistry and orthodontics. 2nd ed., China: Elsevier Limited, 2008: 163,164,223.

5. Hamid MWU, Rahbar MI. Dental crowding and its relationship to tooth size and arch dimensions. Pakistan Oral \& Dent. Jr. 2005; 25(1): 48-50.

6. Proffit WR, Fields HW, Sarver DM. Contemporary orthodontics. 5 th ed., Missouri: Elsevier Inc, 2013: 43, 69-86, 117-9.

7. Flemine, KW, Barest G, O. Sakai. Dental and facial bone abnormalities in pyknodysostosis. ANJR Am J. 2007; 28: 132.

8. Stegeman CA, Davis JR, Boyd LD. The dental hygieniest's guide to nutritional care. 3 rd ed., Canada: Saunders, 2010: 4-6, 230-1.

9. Kementrian Perencanaan Pembangunan Nasional Badan Perencanaan Pembangunan Nasional (BAPPENAS). Rencana aksi nasional pangan dan gizi 2011-2015. <https: Hextranet. who. int/ nutrition /gina/sites/default/files/IDN\%202011\%20Rencana \%20Aksi\%20Nasional\%20Pangan\%20dan\%20Gizi .pdf $>$ (Agustus 5. 2014).

10. Thomaz EBAF, Cangussu MCT, Silva AAMD, Assis AMO. Is malnutrition associated with crowding in permanent dentition?. Int. J. Environ. 2010; 7: 3532 .

11. Thomaz EBAF, Valenca AMG. Relationship between childhood underweight and dental crowding in deciduous teething. J Pediatr. 2009; 85(2): 110-5.

12. Andriany P, Joelimar FA, Djoharnas H. Perbedaan poly kurva keparahan karies gigi susu dan gigi tetap Berta faktor yang berperan pada anak dengan status gizi kurang dan gizi baik. Indonesian Jr.of Denstistry. 2008; 15(2): 248.

13. Portal Resmi Pemko Medan. Kecamatan Medan Baru. http://pemkomedan.go.id/ new/hal medanbaru.html (Agustus 16. 2014).

14. Pramitya AAIM, Valentina TD. Hubungan regulasi diri dengan status gizi pada remaja akhir di Kota Denpasar. Jurnal Psikologi Udayana. 2013. 1(1): 43-9

15. Dwiningsih. Perbedaan asupan energi, protein, lemak, karbohidrat, dan status gizi pada remaja yang 
tinggal di wilayah perkotaan dan pedesaan. 2013. $<$ http://eprints.undip.ac.id/39451/1/514-Dwiningsih G2CO06018.pdf $>$ (Januari 7.2015).

16. Ahammed ARY, Shetty V, Panda AK, Ginda S, Pradhan D, Husain N, et al. Prevalence of malocclusion among 12 to 15 years age group orphan children using Dental Aesthetic Index. The Journal of Contemporary Dental Practice. 2013; 14(1): 111-3.

17. Tak M, Nagarajappa R, Sharda AJ, Asawa K, Tak A, Jalihal S, et al. Prevalence of malocclusion and orthodontic treatment needs among 12-15 years old
School Children of Udaipur, India. European Journal of Dentistry. 2013; 7(1): 47,48.

18. Junior JC, Almeida RCC. Orthosurgical treatment of patients in the growth period: At what cost? Dental Press J Orthod. 2012; 17(1): 159.

19. Poosti M. Jalali T. Tooth Size and Arch Dimension in Uncrowded Versus Crowded Class I Malocclusions. The Journal of Contemporary Dental Practce. $2007 ; 8(3): 1-8$.

20. Iswari H. Gigi supernumerary dan perawatan ortodonsi. Widya Kesehatan dan Lingkungan eJournal. 2013; 1(1): 41. 